Kinestetik : Jurnal Ilmiah Pendidikan Jasmani 5 (4) (2021)

Kinestetik : Jurnal Ilmiah Pendidikan Jasmani

https://ejournal.unib.ac.id/index.php/kinestetik/index

DOI : 10.33369/jk.v5i4.19395

\title{
DEVELOPMENT OF TEACHING MATERIALS GROWTH OF MOTION LEARNING DEVELOPMENT BASED ON ANDROID APPLICATIONS
}

\author{
Alan Alfiansyah Putra Karo Karo ${ }^{1}$, Ika Endah Puspita Sari ${ }^{2}$, Dimas Arif Hidayat ${ }^{3}$, \\ Benny Aprial. M${ }^{4}$, Liliana Puspa Sari ${ }^{5}$ \\ 1,2,3,4, Physical Education, Health and Recreation, Sekolah Tinggi Olahraga dan Kesehaatan \\ Bina Guna, Medan, Indonesia
}

\section{Article Info}

Article History :

Received : December 2021

Revised : December 2021

Accepted : December 2021

Available online : December 2021

\section{Keywords:}

Android, Development, Teaching Materials,

\begin{abstract}
The purpose of this research is the development of teaching materials for motion learning based on android applications. ADDIE is a research model that researchers choose, namely analysis, design, development, implementation and evaluation. The results of the research as a whole are feasible by material experts and media experts on the components of content, language presentation, and graphics, it is obtained that an average percentage of $81.5 \%$ has very high criteria. Based on the overall assessment of the ease of using the product, the difficulty of understanding the material, and the difficulty of doing the questions, the average percentage is $84 \%$ in the very feasible category. The development of teaching materials for the development of motion learning development based on android applications is the result of this research. Based on the results of the study, it can be concluded that the product developed is considered very feasible.
\end{abstract}

\begin{tabular}{llr}
\hline Corresponding address & : Street Aluminium Raya No. 77 & ISSN 2685-6514 (Online) \\
*Corresponding email & $:$ alabalfiansyahputra03@gmail.com & ISSN 2477-331X (Print)
\end{tabular}




\section{INTRODUCTION}

The subject of growth and development of movement learning is a compulsory subject for students at the Bina Guna Health and Sports College. This course has benefits in providing knowledge enrichment to students in the problems associated with the growth and development and movement of students. After completing the course, students are expected to be able to solve problems that occur and provide solutions so that the growth and movement of these students is better than before.

In addition, the implementation of physical education learning that mostly still uses the drill method cannot be used in physical education learning, especially if the facilities and limited infrastructure, because it will cause boredom in the students because time is waiting for their turn to make a move Duty (Yusfi et al., 2021).

The problem of difficulties in learning and carrying out practical activities requires students to be independent in learning the growth and development of movement learning at home. In its situation, the teacher's learning situation uses books and pictures. Books and pictures have not been able to solve the problems faced to learn effectively (Imam Nurseto, 2020). At the higher education level, students are still not independent in learning so that their learning achievement is below the minimum standard (Arista \& Kuswanto, 2018). The results of the study describe the use of applications to support users in teaching (Mota et al., 2018).

The android application is a mobile operating system design, if you want to access it, you can use an android smartphone (Ramadhani \& Lestari, 2018), (Garg \& Baliyan, 2021). The disadvantage of using android applications is that the user's personal information data cannot be protected (Cimino et al., 2020), (Iadarola et al., 2021), (Miller, 2019). Even though it has weaknesses in data security, Android is still the flagship in use in the community.

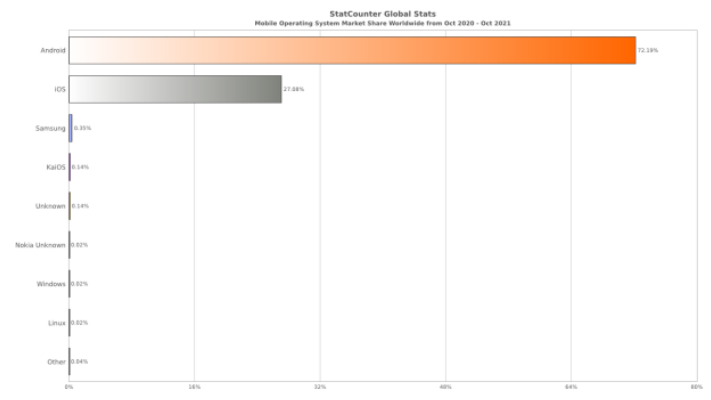

Fig 1. Worldwide Mobile Operating System Market Share Oct 2020 - Oct 2021

From October 2020 to October 2021, smartphone users were ranked first in the world, reaching $72.19 \%$ of the total users. Technological advances in smartphones are on par with personal computers (Garg \& Baliyan, 2021). Many studies confirm that basic programming, internet usage and applications (Sánchez-García et al., 2013) Based on these findings, to overcome practical problems, Androidbased teaching materials can support success in learning (Arun \& Mohit, 2016). 
The novelty in this research can be obtained from previous research. The android application teaching materials created have a menu, namely; profiles, problems, materials, and practice questions (Mitha Frilia et al., 2020), (Nurhalimah et al., 2017), (Sari \& Hapizah, 2020) Based on the results of the study, the researchers added a video menu to the product.

\section{METHODS}

Research and development is a type of research with the development of teaching materials for the development of motion learning as the object of research. ADDIE is the research model that the researcher chose because it is practical and valid (Mitha Frilia et al., 2020), (Nurhalimah et al., 2017) There are five stages in this model, namely analysis, design, development, implementation, evaluation (Castro \& Tumibay, 2021).

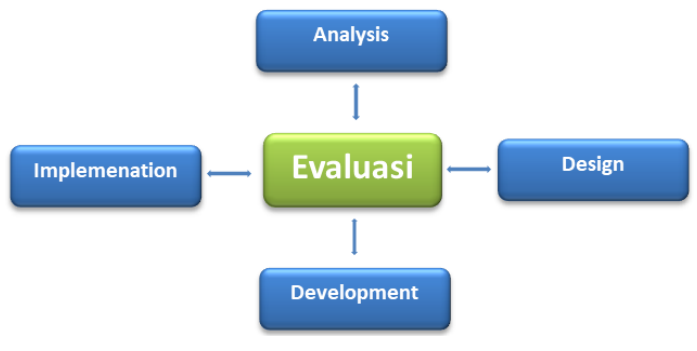

Fig 2. ADDIE Model Research Steps

The design of the development of teaching materials has followed five steps. The analysis step is the initial step or the initial step of the ADDIE model. In this step, three things are done, namely (1) analysis of student achievement, (2) analysis of student attitudes, knowledge, and skills, and (3) analysis of expected material achievements.

The second step of the ADDIE model is design. This step has three stages, namely (1) selected materials and videos according to the student's level and expected achievements, (2) learning methods, and (3) forms of assessment and evaluation. The structure and design of text-based teaching materials for android applications are arranged in each menu. Then, the learning strategies applied to each material are arranged so that the android application-based teaching materials are easy to understand and understand by users.

Development is the third step in developing teaching material products. Finding and enriching material, collecting appropriate data sources, making illustrations, schematics, and graphics, writing, editing, are part of this step. The validators involved are media and materials experts. Analysis and revision of teaching material products.

Fourth is the implementation of teaching materials to students. The development of teaching materials is tested and used by students. Under the time limit, trials of teaching materials were carried out in small groups. After the implementation, a small group consisting of 28 students of Semester III C, Department of Physical Education, Health and Recreation were asked to rate the product.

The fifth step is evaluation. There are two kinds of evaluation, namely formative evaluation which aims 
to validate the product and improve it according to the given revision.

Data collection was obtained through wolktrough, questionnaires and observations. Walkthrough is validating the product by experts. The validation carried out is media and material validation. Products that have been validated will be tested. The trials used were small group trials, and the researchers gave questionnaires to students while making observations based on observational instruments to see the practicality of the product.

For the validation sheet, the expert fills out a sheet that has been prepared by the researcher which has a score for each question item as shown in the table below.

Table 2. Criteria for Validation of Media and Material Experts

\begin{tabular}{cc}
\hline Skore & Criteria \\
\hline $0 \%-20 \%$ & Very Inappropriate \\
\hline $21 \%-40 \%$ & Not feasible \\
\hline $41 \%-60 \%$ & Decent enough \\
\hline $61 \%-80 \%$ & Worthy \\
\hline $81 \%-100 \%$ & Very Worthy \\
\hline
\end{tabular}

Table 3. Student Questionnaire Criteria

\begin{tabular}{cc}
\hline Skore & Criteria \\
\hline $0 \%-20 \%$ & Very Not Good \\
\hline $21 \%-40 \%$ & Not good \\
\hline $41 \%-60 \%$ & Pretty good \\
\hline $61 \%-80 \%$ & Well \\
\hline $81 \%-100 \%$ & Very good \\
\hline
\end{tabular}

The result of the percentage is then determined using the interpretation criteria (Widyastuti \& Susiana, 2019).

\section{RESULT}

The development of teaching materials for the growth of motion learning development based on android applications is the result of this research. The researchers chose the High School of Sports and Health as the research location. Because the college is one of the schools that has implemented blended learning and has a growth subject for movement learning development. The research conducted is as follows.

The analysis stage is carried out to gain more knowledge related to the product. The results of the analysis are used to make products for the development of teaching materials. The tool used in collecting information is a questionnaire related to needs analysis and interviews related to the development of teaching materials for growth and development learning motion learning subjects based on android applications. Based on the needs analysis stage, 73 out of 85 students at Sekolah Tinggi Olahraga dan Kesehatan Bina Guna.

Sekolah Tinggi Olahraga dan Kesehatan Bina Guna uses the curriculum of the Indonesian National Qualifications Framework based on independence to study at an independent campus since 2021. Learning since the COVID-19 pandemic has changed to online-based learning. With the development of teaching materials, it becomes an innovative tool in achieving coursework. Android-based teaching materials present material in the form of videos so that students can better 
understand the material presented in the application.

The design stage of developing teaching materials based on Android applications provides new knowledge and experience in studying the growth and development of motion learning related to students. Android-based teaching materials have an initial display design, application description display, material display, video display, test question display, and reference display.

At this stage, the product is made based on the results of the study and the initial design of teaching materials. The sequence of this stage is: preparing the solubility product and solubility product, doing dubbing, making or collecting several learning videos, making animations, and making software/ multimedia programs (products). The results of the teaching materials that have been developed are presented in the application display and can be seen in Figure 3 below:

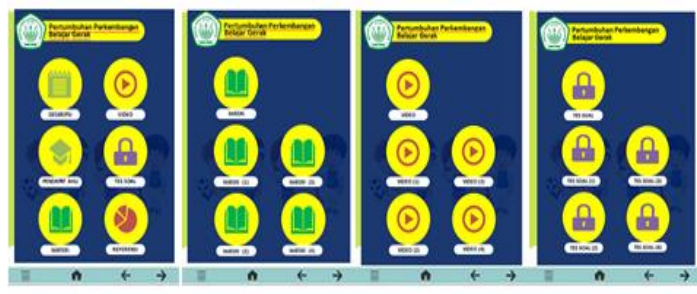

Fig 3. App View

This application operates on Android smartphones. Twenty-four screens were developed on 4 learning materials with 4 videos, 8 pictures, and 4 tables. From 4 materials, 4 videos, 8 pictures were produced by the researcher. The rest comes from the public domain. The source of each image is clearly placed below the image and a hyperlink to the YouTube video.

On the results of the material expert validator, the feasibility of the teaching materials will be assessed using aspects of the feasibility of content and presentation. The language validator is assessed in terms of the feasibility of using the language. In the media validator test, the feasibility of the media on teaching materials will be assessed from the point of view of the display design of andorid teaching materials. The feasibility assessment can be seen in the table below.

Table 4. Feasibility Assessment by Experts

\begin{tabular}{ccccc}
\hline No Component & $\%$ & $\begin{array}{c}\text { Max } \\
\text { Score }\end{array}$ & Criteria \\
\hline 1 & Contents & $80 \%$ & $100 \%$ & Worthy \\
\hline 2 & Presentation & $80 \%$ & $100 \%$ & Worthy \\
\hline 3 & Language & $80 \%$ & $100 \%$ & Worthy \\
\hline 4 & Graphic & $83 \%$ & $100 \%$ & $\begin{array}{c}\text { Very } \\
\text { Worthy }\end{array}$ \\
\hline & Average & $81.5 \%$ & $100 \%$ & $\begin{array}{c}\text { Very } \\
\text { Worthy }\end{array}$ \\
& & & \\
\hline
\end{tabular}

The teaching materials that have been developed have been validated by material and media experts. The results of the assessment of material experts and material experts determine the feasibility of teaching materials and guidelines for revising the products developed. Overall, the results of the assessment by material experts and media experts on the components of content, presentation, discussion and graphics obtained an average percentage of $81.5 \%$ having very decent criteria. 
Teaching materials that have been developed based on input and suggestions from material experts and media experts will be tested to determine student responses to the development of teaching materials for the growth of motion learning development based on android applications to see their attractiveness.

Table 5. Student Response Assessment

\begin{tabular}{ccccc}
\hline No & Component & $\%$ & $\begin{array}{c}\text { Max } \\
\text { Score }\end{array}$ & Criteria \\
\hline 1 & Product Ease & $92 \%$ & $100 \%$ & Very \\
of Use & & & good \\
2 & $\begin{array}{c}\text { Ease of } \\
\text { Understanding } \\
\text { Material }\end{array}$ & $80 \%$ & $100 \%$ & $\begin{array}{c}\text { Very } \\
\text { good }\end{array}$ \\
3 & $\begin{array}{c}\text { Ease of Doing } \\
\text { Test }\end{array}$ & $80 \%$ & $100 \%$ & $\begin{array}{c}\text { Very } \\
\text { good }\end{array}$ \\
& & & Questions \\
Average & $84 \%$ & $100 \%$ & $\begin{array}{c}\text { Very } \\
\text { good }\end{array}$ \\
\hline & & & &
\end{tabular}

Based on this assessment, the overall student response to the ease of using the product, the ease of understanding the material, and the ease of doing the questions obtained an average percentage of $84 \%$ in the very feasible category.

The evaluation phase aims to identify the effectiveness of the product based on the results of the tests conducted on students. The exam is based on a small trial. Based on the test results, it can be concluded that all student scores have reached the specified minimum completeness criteria. In other words, all students have mastered the material, while the percentage of classical completeness is $100 \%$.

Based on the results of research and development obtained, it can be concluded that the teaching materials developed in the form of teaching materials for the growth of the development of learning motion learning based on Android are very feasible and very good.

\section{DISCUSSION}

Learning from home is the best temporary solution, but there must be some weak points in this new learning system that are lacking in the learning process, starting with the socialization system between students and teachers, summative and normative assessment systems, practical learning systems, and many weaknesses. Other of this new learning system (Dennis Dwi Kurniawan, Alfonsus Maria Bandi Utama, 2021).

The factor that influences course achievement is the selection of teaching materials that are arranged appropriately. The selection of the right teaching materials can be carried out according to the respondents or users of teaching materials (P et al., 2019). In developing technology-based products to target behavior change it is often not discussed in detail (Bopp et al., 2016). Research shows that mobile application-based products are becoming more common and effective (Harjanta \& Herlambang, 2018), (Sung \& Park, 2021), (Putri Nandita Apsari, 2018), (Kaneko et al., 2018).

Research result (Almusawi et al., 2021) with the aim of the research being to explore the perspectives of physical education teachers on their readiness to use and integrate wearable technology as 
an innovation in physical education. It involved semi-structured interviews with 38 public school physical education teachers. Based on the thematic analysis of interview data, this study identifies technology that can be applied in physical education. Other research (Gorozidis et al., 2020) educators will be self-motivated when working conditions and training actively contribute to the fulfillment of their innate psychological needs.

\section{CONCLUSION}

The development of teaching materials for the growth of motion learning development based on android applications is the result of this research. Based on the results of the assessment of material experts and material experts determine the feasibility of teaching materials and guidelines for revising the products developed. Overall, the results of the assessment by material experts and media experts on the components of content, presentation, discussion and graphics as well as assessing product user responses have very decent criteria.

\section{ACKNOWLEDGEMENT}

The authors would like to thank the Bina Guna College of Sports and Health which has given permission to carry out research, as well as to providers of research funds sourced from the Ministry of Education and Culture.

\section{REFERENCES}

Almusawi, H. A., Durugbo, C. M., \& Bugawa, A. M. (2021).
Innovation In Physical

Education: Teachers'

Perspectives On Readiness For Wearable Technology

Integration. Computers And Education, 167(February), 104185.

Https://Doi.Org/10.1016/J.Comp edu.2021.104185

Arista, F. S., \& Kuswanto, H. (2018). Virtual Physics Laboratory Application Based On The Android Smartphone To Improve Learning Independence And Conceptual Understanding. International Journal Of Instruction, 11(1), 1-16. Https://Doi.Org/10.12973/Iji.20 18.1111a

Arun, J., \& Mohit, J. (2016). A Novel Smart Metering Infrastructure Using Virtual Instrument. Indian Journal of Science And Technology, 9(12), 1-6. Https://Doi.Org/10.17485/Ijst/20 16/V9i12/89919

Bopp, M., Sims, D., Matthews, S. A., Rovniak, L. S., Poole, E., \& Colgan, J. (2016). There'S An App For That: Development Of A Smartphone App To Promote Active Travel To A College Campus. Journal Of Transport And Health, 3(3), 305-314. Https://Doi.Org/10.1016/J.Jth.20 16.02.007

Castro, M. D. B., \& Tumibay, G. M. (2021). A Literature Review: Efficacy Of Online Learning Courses For Higher Education Institution Using Meta-Analysis. Education And Information Technologies, 26(2), 13671385.

Https://Doi.Org/10.1007/S10639 -019-10027-Z

Cimino, M. G. C. A., De Francesco, N., Mercaldo, F., Santone, A., \& 
Vaglini, G. (2020). Model Checking For Malicious Family Detection And Phylogenetic Analysis In Mobile Environment. Computers And Security, $\quad 90, \quad 101691$. Https://Doi.Org/10.1016/J.Cose. 2019.101691

Dennis Dwi Kurniawan, Alfonsus Maria Bandi Utama, R. M. (2021). The Application Of Hand-Eye Coordination Test Guidelines For Table Tennis Using Audio Visual Media Dennis Dwi Kurniawan 1 , Alfonsus Maria Bandi Utama 2 , Rizki Mulyawan 3. Jurnal Sportif: Jurnal Penelitian Pembelajaran, 7(2), 232-247.

Garg, S., \& Baliyan, N. (2021). Comparative Analysis Of Android And Ios From Security Viewpoint. Computer Science Review, 40, 100372. Https://Doi.Org/10.1016/J.Cosre v.2021.100372

Gorozidis, G. S., Tzioumakis, Y. S., Krommidas, C., \& Papaioannou, A. G. (2020). Facebook Group Petcon (Physical Education Teacher Collaborative Network). An Innovative Approach To Pe Teacher InService Training: A SelfDetermination Theory Perspective. Teaching And Teacher Education, 96, 103184. Https://Doi.Org/10.1016/J.Tate. 2020.103184

Harjanta, A. T. J., \& Herlambang, B. A. (2018). Rancang Bangun Game Edukasi Pemilihan Gubernur Jateng Berbasis Android Dengan Model Addie. Jurnal Transformatika, 16(1), 91. Https://Doi.Org/10.26623/Transf ormatika.V16i1.894

Iadarola, G., Martinelli, F., Mercaldo, F.,
\& Santone, A. (2021). Towards An Interpretable Deep Learning Model For Mobile Malware Detection And Family Identification. Computers And Security, 105, 102198. Https://Doi.Org/10.1016/J.Cose. 2021.102198

Imam Nurseto, S. (2020). Pengembangan Mobile Learning Senam Lantai Dbl Berbasis Android Untuk Kelas Vii Smp Develpoment Of Mobile Learning Gymnastics Dbl Based On Android For Seven Grade Of Junior High School. Jurnal Pendidikan Jasmani Indonesia, 16(2), 132-144.

Kaneko, K., Saito, Y., Nohara, Y., Kudo, E., \& Yamada, M. (2018). Does Physical Activity Enhance Learning Performance?: Learning Effectiveness Of Game-Based Experiential Learning For University Library Instruction. Journal of Academic Librarianship, 44(5), 569-581.

Https://Doi.Org/10.1016/J.Acali b.2018.06.002

Miller, T. (2019). Explanation In Artificial Intelligence: Insights From The Social Sciences. Artificial Intelligence, 267, 138.

Https://Doi.Org/10.1016/J.Artint .2018 .07 .007

Mitha Frilia, Hapizah, Susanti, E., \& Scristia, S. (2020). Pengembangan Bahan Ajar Materi Prisma Berbasis Android Untuk Pembelajaran Berbasis Masalah Di Kelas Viii. Jurnal Gantang, 5(2), 191-201. Https://Doi.Org/10.31629/Jg.V5 i2. 2362

Mota, J. M., Ruiz-Rube, I., Dodero, J. M., \& Arnedillo-Sánchez, I. 
(2018). Augmented Reality Mobile App Development For All. Computers And Electrical Engineering, 65, 250-260. Https://Doi.Org/10.1016/J.Comp eleceng.2017.08.025

Nurhalimah, S. R., Suhartono, S., \& Cahyana, U. (2017). Pengembangan Media Pembelajaran Mobile Learning Berbasis Android Pada Materi Sifat Koligatif Larutan. Jrpk: Jurnal Riset Pendidikan Kimia, $7(2)$, 160-167. Https://Doi.Org/10.21009/Jrpk.0 72.10

P, B. P. K., Ali, R. N., \& Sulistiyowati, E. (2019). Pengembangan Media Pembelajaran Biodiversitas Berbasis Android. Journal of Tropical Chemistry Research And Education, 1(1), 36-42. Https://Doi.Org/10.37079/Jtcre. V1i1.21

Putri Nandita Apsari, S. R. (2018). Media Pembelajaran Matematika Berbasis Android Pada Materi Program Linear. Aksioma: Jurnal Program Studi Pendidikan Matematika, 7(1), 161-170.

Https://Doi.Org/10.1299/Jsmem ag.121.1191_47

Ramadhani, D., \& Lestari, I. (2018). Pengembangan Bahan Ajar Listrik Magnet Berbasis Android Di Program Studi Pendidikan. Jurnal Pmipa, 9 No 1, 99, 99-107. Http://Jurnal.Untan.Ac.Id/Index. Php/Pmp/Article/View/23703

Sánchez-García, A.-B., Marcos, J.-J. M., Guanlin, H., \& Escribano, J. P. (2013). Teacher Development And Ict: The Effectiveness Of A Training Program For In-Service School Teachers. Procedia Social And Behavioral Sciences,
92(Lumen), 529-534. Https://Doi.Org/10.1016/J.Sbspr o.2013.08.713

Sari, R. M., \& Hapizah, H. (2020). Pengembangan Bahan Ajar Program Linear Berbasis Android Untuk Pembelajaran Berbasis Masalah. Kreano, Jurnal Matematika KreatifInovatif, 11(2), 168-182. Https://Journal.Unnes.Ac.Id/Nju /Index.Php/Kreano/Article/View /25278/11169

Sung, S., \& Park, H. A. (2021). Effect Of A Mobile App-Based Cultural Competence Training Program For Nurses: A PreAnd Posttest Design. Nurse Education Today, 99(January), 104795.

Https://Doi.Org/10.1016/J.Nedt. 2021.104795

Widyastuti, E., \& Susiana. (2019). Using The Addie Model To Develop Learning Material For Actuarial Mathematics. Journal of Physics: Conference Series, 1188(1).

Https://Doi.Org/10.1088/17426596/1188/1/012052

Yusfi, H., Solahuddin, S., Bayu, W. I., Education, S., Sriwijaya, U., Education, P., Sriwijaya, U., \& Info, A. (2021). Kinestetik: Jurnal Ilmiah Pendidikan Jasmani Content Validity Index Development Of Learning. 5(3), 571-579. 